\title{
Micro-structural characterization of supermartensitic stainless steel coating modified with boro processed by HVOF
}

\author{
Santos, L. S. ${ }^{1}$; Coimbrão, D.D. ${ }^{12^{*}}$; Botta, W.J. ${ }^{1}$; Zepon, G. ${ }^{1}$ \\ 1. Programa de Pós-graduação em Ciência e Engenharia de Materiais, Universidade Federal de São Carlos, \\ São Carlos-SP, Brazil. \\ 2. Departamento de Engenharia de Materiais, Universidade Federal de São Carlos, São Carlos-SP, Brazil. \\ * Corresponding author: fdiego@ufscar.br
}

Stainless steels are recognized as good materials to be used in corrosive environments, but their wear resistance does not exhibit good results. Therefore, there is increasing interest in the development of stainless steels with optimized wear resistance by the addition of boron. Significant improvements in wear resistance were obtained by the addition of boron in the supermartensitic stainless steels processed by spray forming due to the formation of hard $\mathrm{M}_{2} \mathrm{~B}$ borides in the microstructure. The objective of this work has the production of HVOF (High Velocity Oxygen Fuel) coatings of the modified supermatensitic steel with $0.7 \%$ wt. of boron (SM-14Cr-0.7B), its microstructural characterization and evaluation of the wear properties. The coatings were produced using powders in two distinct particle sizes, $0-20 \mu \mathrm{m}$ and $20-53 \mu \mathrm{m}$. The powders and coatings were characterized by optical microscopy (OM), scanning electron microscopy (SEM), X-ray diffraction (XRD). The two particle sizes presented microstructures composed of martensite, retained austenite and $\mathrm{M}_{2} \mathrm{~B}$ type borides. The coating obtained with powders of 20-53 $\mu \mathrm{m}$ granulometry presented in its microstructure a small amount of oxides and borides of type $\mathrm{M}_{2} \mathrm{~B}$ in two forms: coarser borides in the form of a three-dimensional network interconnected; and in the form of spherical precipitates of the order of $100 \mathrm{~nm}$ or less distributed within the martensitic matrix. The coating obtained by the powders of $0-20 \mu \mathrm{m}$ granulometry presented a low average thickness and a high amount of oxides. The wear rate obtained by the pin-on-disc test for the SM-14Cr-0.7B coating processed by HVOF using the powders of particle size 20-53 $\mu \mathrm{m}$ was approximately one order of magnitude lower than that obtained for AISI 1020 steel, unmodified supermartensitic steel, and SM-14Cr-0.7B steel processed by spray forming. Figures 1 (a) and (b) show the electron diffraction pattern of the coating region overlapped with the theoretical polycrystalline diffraction patterns for BCC-Fe (low carbon martensite) and $\mathrm{Cr}_{2} \mathrm{~B}$ boride (Fddd space group), respectively. It can be seen that all $\mathrm{Fe}$ reflections coincide with some $\mathrm{Cr}_{2} \mathrm{~B}$ reflection, making it difficult to make dark field images with just one phase. Figures 1 (c) and (d) show dark field images obtained with the lens aperture positioned at positions 1 and 2 (see figure 1 (a) and (b)), respectively. By the morphology of the phases, it was possible to observe the $\mathrm{Cr}_{2} \mathrm{~B}$ (or $\mathrm{M}_{2} \mathrm{~B}$ ) borides, which diffracted in the direction selected by the objective aperture, confirming the presence of borides with sizes of the order of $200 \mathrm{~nm}$. The EDX mapping presented in Figure 2 shows that the boride phases are rich in $\mathrm{Cr}$ and depleted in Fe, Mo and Ni. Previous work has reported that the $\mathrm{M}_{2} \mathrm{~B}$-type borides in boron modified supermartensitic stainless steels are typically rich in $\mathrm{Cr}$.

\section{References:}

[1] LIU, X. Q.; ZHENG, Y. G.; CHANG, X. C.; HOU, W. L.; WANG, J. Q.; TANG, Z.; BURGUESS, A. Microstructure and properties of Fe-based amorphous metallic coating produced by high velocity axial plasma spraying, Journal of Alloys and Compounds, v. 484, n. 1-2, p. 300-307, 2009.

[2] SIGOLO, E. SOYAMA, J.; ZEPON, G.; KIMINAMI, C. S.; BOTTA, W. J.; BOLFARINI, C. Wear resistant coatings of boron-modified stainless steels deposited by Plasma Transferred Arc, Surface \& Coatings Technology, vol:302 pg:255 -264, 2016

[3] ZEPON, G. Desenvolvimento do aço inoxidável supermartensítico resistente ao desgaste por conformação por spray para aplicação em risers. Dissertação (Mestrado em Ciência e Engenharia de Materiais) - Universidade Federal de São Carlos. São Carlos, 2013

[4] The authors acknowledge CAPES, FAPESP (projeto temático n. 2013/05987-8) and CNPq. 

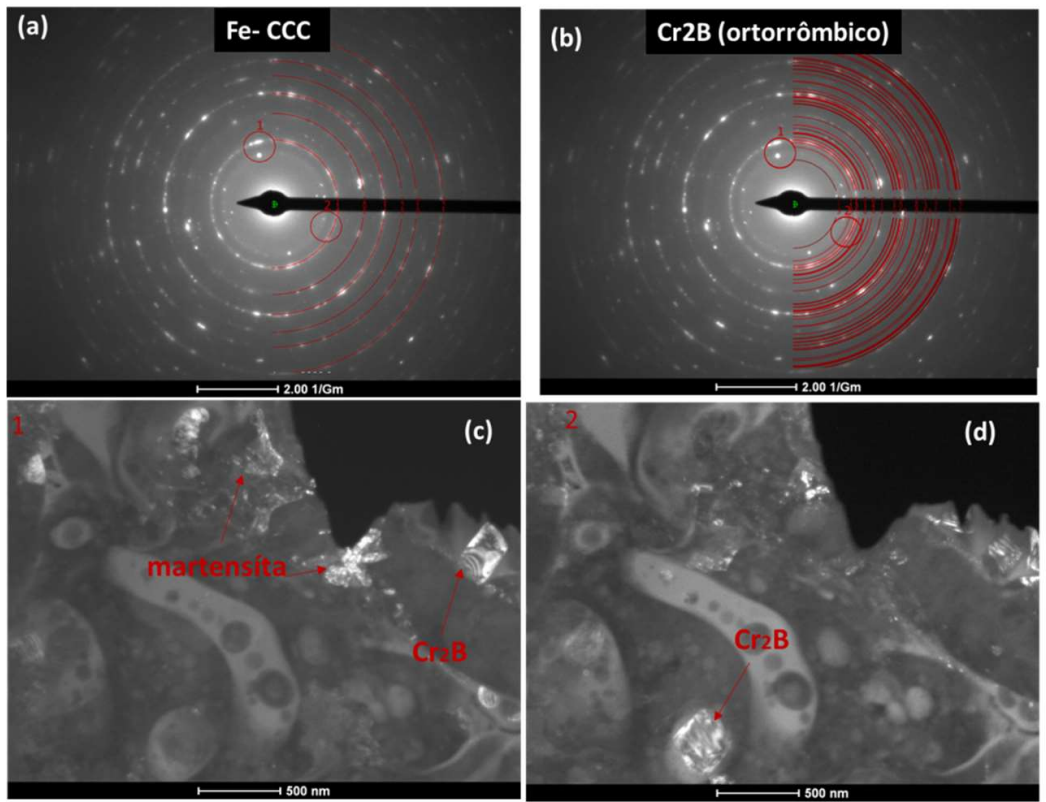

Figure 1. (a) and (b) show the electron diffraction pattern of the coating region overlapped with the theoretical polycrystalline diffraction patterns for BCC-Fe (low carbon martensite) and $\mathrm{Cr}_{2} \mathrm{~B}$ boride (Fddd space group), respectively. It can be seen that all Fe reflections coincide with some $\mathrm{Cr}_{2} \mathrm{~B}$ reflection, making it difficult to make dark field images with just one phase. Figures 1 (c) and (d) show dark field images obtained with the lens aperture positioned at positions 1 and 2 (see figure 1 (a) and (b)), respectively.

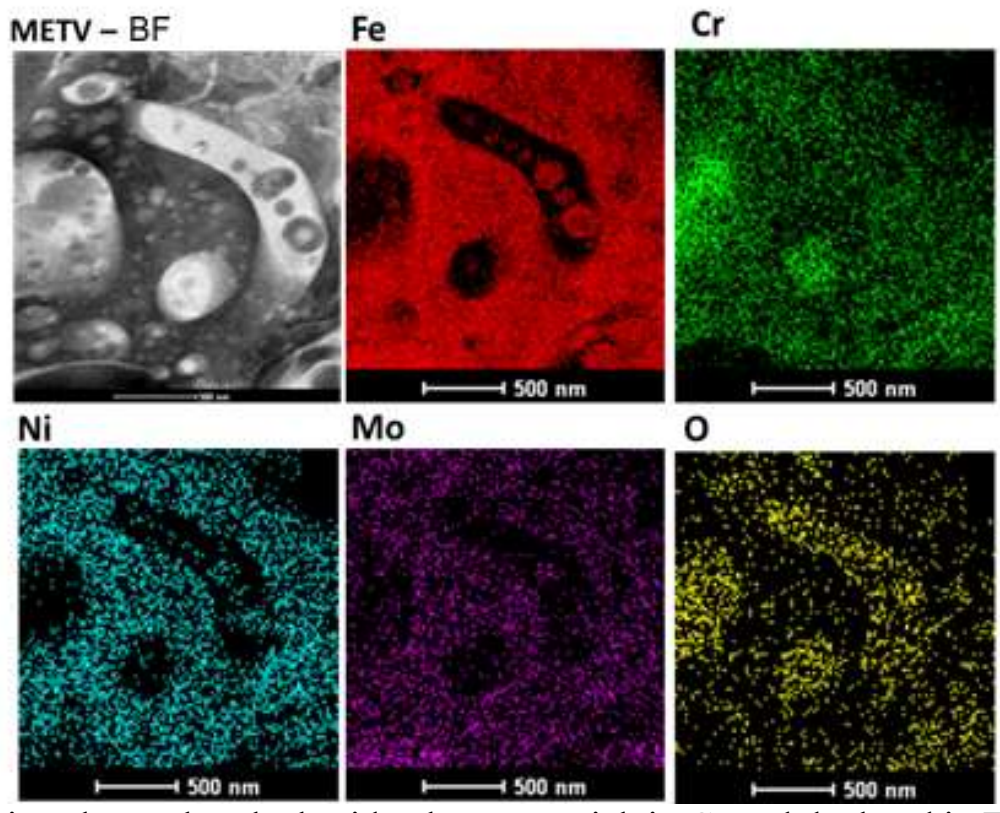

Figure 2. EDX mapping shows that the boride phases are rich in $\mathrm{Cr}$ and depleted in $\mathrm{Fe}, \mathrm{Mo}$ and $\mathrm{Ni}$. 